\title{
Type 2 Diabetes Mellitus is Associated with Lower Serum Adiponectin Level in Bangladeshi Population
}

\author{
*SN Eva1 ${ }^{1}$ R Zinnat ${ }^{2}$, GM Molla ${ }^{3}, \mathrm{M} \mathrm{Zahir}^{4}$, F Akter ${ }^{5}$, B Rehnuma ${ }^{6}$, R Amin ${ }^{7}$ \\ 1*Dr. Sohely Nazneen Eva, Assistant Professor, Department of Biochemistry, Ashiyan Medical College, Dhaka \\ 2Dr. Rahelee Zinnat, Associate Professor, Department of Biochemistry \& Cell Biology, Bangladesh University of Health Science, Dhaka \\ 3Dr. Golam Morshed Molla, Associate Professor, Department of Biochemistry, Ashiyan Medical College, Dhaka \\ 4Dr. Muneera Zahir, Assistant Professor, Department of Anatomy, Ashiyan Medical College, Dhaka \\ 5Dr. Fatema Akter, Assistant Professor, Department of Biochemistry, Ashiyan Medical College, Dhaka \\ ${ }^{6}$ Dr. Behterin Rehnuma, Registrar, Department of Biochemistry, Apollo Hospitals, Dhaka
}

7Dr. Rukhsana Amin, Assistant Professor of Pharmacology

*Corresponding Author

\begin{abstract}
Background: The physiological role of adiponectin is not yet fully clear, but it is now generally accepted that it has a protective role against the development of lifestyle disorders, related to insulin resistance and atherosclerosis. Insulin resistance is one of the basic defects of type 2 diabetes (T2DM) and adiponectin is inversely associated with T2DM. As serum adiponectin level has not yet been investigated in Bangladeshi T2DM subjects,so that the present study has been under taken to find out the association of T2DM with serum adiponectin level in Bangladeshi population.

Methodology: In this observational case control study, sixty six (66) T2DM subjects, seventy four (74) healthy control subjects were included. Diabetes was diagnosed and classified as per WHO criteria. Serum Adiponectin was measured by Enzyme Linked Immunosorbent Assay (ELISA) method. Serum glucose was measured by glucose-oxidase method; serum insulin was measured by chemiluminescence-based ELISA technique. The insulin secretory capacity (HOMA\%B), insulin sensitivity (HOMA\%S) \& insulin resistance (HOMA IR) were assayed by homeostasis model assessment method.
\end{abstract}

Results: The study subjects were BMI matched. BMI of the Control subjects and T2DM subjects (Mean \pm SD) were $25.02 \pm 3.55$ and $25.85 \pm 3.62$. Age (year) of the Control subjects and T2DM subjects (Mean \pm SD) were $42.46 \pm 9.24$ and $48.49 \pm 8.09$. Median (range) fasting serum insulin in the control and T2DM was 14.68 (1.86-45.92) and 18.09 (4.10-42.78) respectively which was not statistically significant $(\mathrm{p}=0.214)$. Median (range) HOMA\%B values in the control and T2DM subjects was 160.10(33.40-493.40) and 100.45(17.70-349.30). Median HOMA\%B in the T2DM group was significantly lower compared to the control $(\mathrm{p}=0.0001)$. Median (range) HOMA\%S values in the control and T2DM subjects was 44.20(9.80339.40) and 32.80(14.30-154.70) respectively. Median HOMA\%S in the T2DM group was significantly lower compared to the control $(\mathrm{p}=0.036)$. Median (range) serum adiponectin $(\mu \mathrm{g} / \mathrm{ml})$ of the control and T2DM subjects was $8.70(0.76-15.96)$ and 6.19 (1.13-22.37). Serum adiponectin was significantly lower in T2DM compared to the control $(\mathrm{p}=0.0001)$.

Conclusions: From this study it may be concluded that, T2DM subjects have both insulin secretory defects and insulin resistance and associated with lower serum adiponectin level in Bangladeshi population.

Key Word: T2DM, Adiponectin, Insulin sensitivity, Insulin resistance

\section{Introduction}

It has been estimated that the total diabetic patients in Bangladesh was more than 3 million in 2000, and this number would rise to 11.1 million by the 2030 . The proportional increase in Bangladesh seemed relatively higher compared to other Asian countries ${ }^{1}$. An epidemiological study has revealed that the prevalence of DM in Bangladesh had increased exponentially in urban and rural populations which is double in urban than in rural areas ( $8 \%$ vs. $4 \%)$ and rises with affluence 2 . Age adjusted prevalence of T2DM was about 5.6\% among the rural population ${ }^{3}$. This creates a great challenge to the health care system in the developing country like Bangladesh, since diabetes is a lifelong disease and requiring daily treatment3. Several pathogenic processes are involved in the development of diabetes. These range from autoimmune destruction of the $\beta$-cells of the 
pancreas with consequent insulin deficiency to abnormalities that result in resistance to insulin action. Impairment of insulin secretion and defects in insulin action frequently coexist in the same patient, and it is often unclear which abnormality, if either alone, is the primary cause of the hyperglycemia ${ }^{4}$.

Excess adiposity is one of the most important risk factor for the development of insulin resistance and type 2 diabetes $^{5}$. Adipose tissue, in addition to being a fat store, secretes a number of hormones and proteins collectively termed adipokines ${ }^{6,7}$. Of all the adipokines, adiponectin has drawn special attention, largely due to its effects on both insulin sensitivity and inflammation ${ }^{8}$.

In healthy nonobese subjects, the plasma level of adiponectin is $4-14 \mu \mathrm{g} / \mathrm{ml}^{9,10}$ and according to Funahashi and Matsuzawa ${ }^{11}$, the concentration of adiponectin, ranges from 4 to $30 \mu \mathrm{g} / \mathrm{mL}$ in the blood. Although the physiological role of adiponectin is yet to be determined, but it has been proposed that it has protective effects against the development of atherosclerosis ${ }^{12,13}$ and animal studies and cell culture experiments have shown that direct stimulation of nitric oxide synthesis is responsible for the anti-inflammatory mechanism and antiatherogenic effects of adiponectin ${ }^{14}$. Some found that administration of adiponectin decreased the attachment of monocytic cell to human aortic endothelial cells which is an early event in atherosclerotic vascular damage ${ }^{13,15}$. These clinical and experimental observations suggest that adiponectin plays some protective role against the atherosclerotic vascular change and decreased plasma adiponectin in type 2 diabetic patients may contribute to the development of atherosclerotic complications ${ }^{16}$. Though adiponectin has no effect on normal insulin secretion, but diminishes the pro-apoptotic effects of cytokines and FFA on $\beta$-cells ${ }^{16}$. A prospective study shows that higher adiponectin levels are consistently associated with a lower risk of type 2 diabetes across diverse populations ${ }^{17}$. Low concentration of adiponectin predicted subsequent development of IGR and T2DM in initially normoglycemic middle aged people ${ }^{18}$.

Low adiponectin is shown to be predictive of future diabetes in many populations, including the Asian Indians ${ }^{19,20}$. It is now established that, adiponectin is one of the strongest and most consistent biochemical predictors of type 2 diabetes ${ }^{21}$.

In a series of studies on Bangladeshi population to investigate the basic defects of T2DM both insulin secretory defect and insulin resistance had been found $22-24$. Another study has showed that T2DM have evidence of subclinical inflammation which is associated with insulin resistance but not with insulin secretory defect in Bangladeshi population 25 . In a recent study in Bangladesh, it was found that ratio of fasting glucose to adiponectin may be an important factor for the development of type 2 diabetes and associated with insulin sensitivity and insulin secretory capacity in prediabetic or IGR subjects ${ }^{26}$.

Based on the above findings and as serum adiponectin level has not yet been investigated in Bangladeshi T2DM subjects, this study has been under taken to find out the level of serum adiponectin in Bangladeshi T2DM subjects.

\section{Material and Methods}

This observational case control study was conducted in the Biomedical Research Group, Research Division, Bangladesh Institute of Research and Rehabilitation in Diabetes, Endocrine and Metabolic Disorders (BIRDEM), Dhaka, Bangladesh from July 2011 to June 2012. Total 140 (one hundred and forty) subjects were recruited in this study irrespectively of race, religion and socioeconomic status. Out of 140, 74 subjects were healthy control and 66 were T2DM subjects respectively who were BMI matched. Diabetes was diagnosed and classified as per WHO criteria. Serum Adiponectin was measured by Enzyme Linked Immunosorbent Assay (ELISA) method. Serum glucose was measured by glucose-oxidase method. Serum insulin was measured by chemiluminescence-based ELISA technique. The insulin secretory capacity (HOMA\%B), insulin sensitivity (HOMA\%S) \& insulin resistance (HOMA IR) were assayed by homeostasis model assessment method. The data were analyzed by appropriate univariate, bivariate and multivariate statistical tests.

\section{Results}

BMI of the Control and T2DM subjects (Mean \pm SD) were $25.02 \pm 3.55$ and 25.85 $\pm 3.62,(p=0.172)$ (Table 1). Age (year) of the Control and T2DM subjects $($ Mean \pm SD) was $42.46 \pm 9.24$ and $48.49 \pm 8.09$ (Table 1). Median (range) fasting serum insulin $(\mu \mathrm{IU} / \mathrm{ml})$ in the control and T2DM was 14.68 (1.86-45.92) and 18.09 (4.10-42.78) respectively which did not show statistical significance difference $(p=0.214)$ (Table 2). Median (range) HOMA\%B values in the control and T2DM subjects was 160.10(33.40-493.40) and 100.45(17.70349.30). Median HOMA\%B in the T2DM group was significantly lower compared to the control $(\mathrm{p}=0.0001)$ (Table 2). Median (range) HOMA\%S values in the control and T2DM subjects was 44.20(9.80-339.40) and $32.80(14.30-154.70)$ respectively. Median HOMA\%S in the T2DM group was significantly lower compared to the control $(\mathrm{p}=0.036)$ (Table 2). Median (range) serum adiponectin $(\mu \mathrm{g} / \mathrm{ml})$ of the control and T2DM subjects 
was 8.70 (0.76-15.96) and 6.19 (1.13-22.37) (Fig 1). Serum adiponectin was significantly lower in T2DM compared to the control $(\mathrm{p}=0.0001)$.

Table-I: Anthropometric measurements of the study subjects.

\begin{tabular}{lccc}
\hline Variables & $\begin{array}{c}\text { Control } \\
(\mathbf{n}=74)\end{array}$ & $\begin{array}{c}\text { T2DM } \\
(\mathbf{n}=66)\end{array}$ & $\begin{array}{c}\text { p values } \\
\text { Control vs T2DM }\end{array}$ \\
\hline Age (years) & $42.46 \pm 9.24$ & $48.49 \pm 8.09$ & $4.114 / 0.0001$ \\
$(\mathrm{Mean} \pm \mathrm{SD}$ & & & \\
$\mathrm{BMI}(\mathrm{kg} / \mathrm{m})^{2}$ & $25.02 \pm 3.55$ & $25.85 \pm 3.62$ & $1.372 / 0.172$ \\
\hline
\end{tabular}

Table-II: Glycemic status of the study subjects

\begin{tabular}{llll}
\hline Variables & $\begin{array}{l}\text { Control } \\
(\mathrm{n}=74)\end{array}$ & $\begin{array}{l}\text { T2DM } \\
(\mathrm{n}=66)\end{array}$ & $\begin{array}{c}\mathrm{p} \text { va lues } \\
(\text { Control vs T2DM })\end{array}$ \\
\hline FSG $(\mathrm{mmmol} / \mathrm{L})$ & $5.3(4.2-6)$ & $7(4.3-15.4)$ & $7.583 / 0.0001$ \\
F Insulin $(\mu \mathrm{I} \mathrm{U} / \mathrm{ml})$ & $14.68(1.86-45.92)$ & $18.09(4.10-42.78)$ & $1.242 / 0.214$ \\
HOMA\%B & $160.10(33.40-493.40)$ & $100.45(17.70-349.30)$ & $4.714 / 0.0001$ \\
HOMA\% & $44.20(9.80-339.40)$ & $32.80(14.30-154.70)$ & $2.096 / 0.036$ \\
HOMA IR & $3.49(0.46-11.43)$ & $5.77(1-28.34)$ & $4.673 / 0.0001$ \\
\hline
\end{tabular}

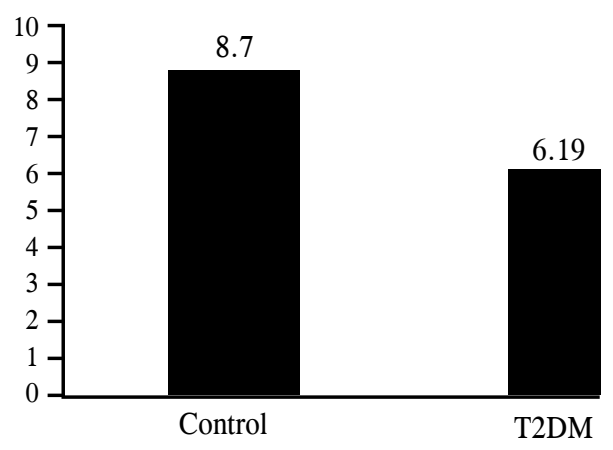

Fig1: Serum adiponectin level in the study subjects

\section{Discussion}

The physiological role of adiponectin is not yet fully clear, but it is now generally accepted that it has a protective role against the development of lifestyle disorders related to insulin resistance and atherosclerosis. Insulin resistance is one of the basic defects of T2DM and serum adiponectin level is inversely associated with insulin resistance. This study was aimed to assess the serum adiponection level in Bangladeshi T2DM subjects. Serum adiponectin, Serum insulin, Insulin secretory capacity (HOMA\%B), Insulin sensitivity (HOMA\%S) and Insulin resistance (HOMAIR) of sixty-six (66) T2DM and seventy four (74) healthy control subjects were measured. The median (range) serum adiponectin $(\mu \mathrm{g} / \mathrm{ml})$ of the control subjects was $8.70(0.76-15.96)$ which was within normal range (4 - $14 \mu \mathrm{g} / \mathrm{ml})^{9,10}$. This result was also compatible with only one study done in Bangladeshi population (1.9-19 $\mu \mathrm{g} / \mathrm{ml}) 27$. Lower limit of serum adiponectin level in this study was below the normal level of previous studies. It may be due to small sample size, age difference, BMI difference. The median (range) serum adiponectin $(\mu \mathrm{g} / \mathrm{ml})$ of the T2DM subjects was 6.19 (1.13-22.37). This result was consistent with the other studies $^{9,10}$. This result was also compatible with IGR population in Bangladesh ${ }^{27}$. Serum adiponectin level of T2DM subjects was significantly lower than the control subjects $(p=0.0001)$. It indicates that low serum adiponectin level is associated with T2DM in Bangladeshi population. From group difference analysis it seems evident that serum adiponectin has an inverse association with T2DM which indicates serum adiponectin level is inversely associated with T2DM. This finding was consistent with other studies ${ }^{28,29,30,32}$. Median HOMA\%B of T2DM group was significantly lower than the control subjects $(p=0.0001)$. It indicates T2DM subjects in this study have insulin secretory defects. The median HOMA\%S of T2DM subjects was significantly lower than the control subjects $(\mathrm{p}=0.036)$. The median (range) HOMA IR of control and T2DM subjects were $3.49(0.46-11.43)$ and 5.77(1.0-28.34). The median HOMA IR of T2DM subjects was significantly higher than the control subjects $(\mathrm{P}=0.0001)$. These findings indicate $\mathrm{T} 2 \mathrm{DM}$ subjects in this study have insulin resistance. Impairment of insulin secretion and defects in insulin action frequently coexist in the same T2DM patients ${ }^{4}$.

\section{Conclusions}

From the findings of this study, it may be concluded that T2DM subjects have both insulin secretory defects and insulin resistance; and serum adiponectin level was significantly lower in T2DM subjects in Bangladeshi population.

\section{Conflict of interest: none}

\section{References}

1. Wild S, Roglic G, Green A, et al. Global Prevalence of Diabetes: Estimates for the year 2000 and projections for 2030. Diabetes Care 2004; 27: 1047-1053.

2. Ghaffar A, Reddy KS, Singhi M. Burden of noncommunicable diseases in South Asia. BMJ 2004; 328: 807810 .

3. Sayeed MA, Hussain MZ, Banu A, et al. Prevalence of diabetes in a suburban population of Bangladesh. Diabetes Res Clin Pract 2007; 34: 149-155. 
4. American Diabetes Association (ADA). Diagnosis and classification of diabetes mellitus. Diabetes Care 2004; 27(1): 5-10.

5. Wilding JPH. Obesity and nutritional factors in the pathogenesis of type 2 diabetes mellitus. Textbook of Diabetes. 3rd edn. Pickup JC, Ed. Oxford, U.K., Blackwell Science Ltd., 2003: 21.21 -21.16.

6. Guerre-Millo M. Adipose tissue and adipokines: for better or worse. Diabetes Metab 2004; 30: 13-19.

7. Trayhurn P, Wood IS. Signalling role of adipose tissue: adipokines and inflammation in obesity. Biochem Soc Trans 2005; 33: 1078-1081.

8. Menzaghi C, Trischitta V, Doria A. Genetic influences of adiponectin on insulin resistance, type 2 diabetes, and cardiovascular disease. Diabetes 2007; 56(5): 1198-1209.

9. Arita $\mathrm{Y}$, Kihara S, Ouchi N, et al. Paradoxical decrease of an adipose-specific protein, adiponectin, in obesity. Biochem Biophys Res Commun 1999; 257: 79-83

10. Hotta K, Funahashi T, Arita Y, et al. Plasma concentrations of a novel, adipose-specific protein, adiponectin, in type 2 diabetic patients. Arterioscler Thromb Vasc Biol 2000; 20: 1595-1599

11. Funahashi T, Matsuzawa Y. Hypoadiponectinemia: a common basis for diseases associated with overnutrition. Curr Atheroscler Rep 2006; 8: 433-438

12. Okamoto Y, Arita Y, Nishida M, et al. An adipocytederived plasma protein, adiponectin, adheres to injured vascular walls. Horm Metab Res 2000; 32: 47-50.

13. Ouchi N, Kihara S, Arita Y, et al. Novel modulator for endothelial adhesion molecules: adipocyte-derived plasma protein adiponectin. Circulation 1999; 100: 2473-2476

14. Antoniades C, Antonopoulos AS, Tousoulis D, et al. Adiponectin: from obesity to cardiovascular disease. Obes Rev 2009; 10: 269-279

15. Ouchi N, Kihara S, Arita Y, et al. Adiponectin, an adipocytederived plasma protein, inhibits endothelial NF-?B signaling through a cAMP-dependent pathway. Circulation 2000; 102: 1296-1301

16. Zhao YF, Feng DD, Chen C. Contribution of adipocytederived factors to beta-cell dysfunction in diabetes. Int $\mathrm{J}$ Biochem Cell Biol 2006; 38: 804-819.

17. Li S, Shin JJ, Ding EL, van Dam RM. Adiponectin levels and risk of type 2 diabetes: a systematic review and metaanalysis. JAMA 2009; 302: 179-188.

18. Sattar N, Wannamethee SG, Forouhi N. Novel biochemical risk factors for type 2 diabetes: pathogenic insights or prediction possibilities? Diabetologia 2008; 51(6): 926-940.
19. Jalovaara K, Santaniemi M, Timonen M, et al. Low serum adiponectin level as a predictor of impaired glucose regulation and type 2 diabetes mellitus in a middle-aged Finnish population. Metabolism 2008; 57(8): 1130-1134.

20. Snehalatha C, Ramachandran A, Mukesh B, et al. Plasma adiponectin is an independent predictor of type 2 diabetes in Asian Indians. Diabetes Care 2003; 26:3226-3229

21. Lindsay RS, Funahashi T, Hanson RL, et al. Adiponectin and development of type 2 diabetes in the Pima Indian population. Lancet 2002; 360: 57-58

22. Zinnat R, Junaid MM, Khan $\mathrm{AH}$, et al. Insulin secretory dysfunction and insulin resistance in Bangladeshi obese Type 2 diabetic subjects. Diabetes Metab 1999; 29: 4S103.

23. Junaid MM. Insulin resistance and insulin secretory dysfunction in obese Bangladeshi type 2 diabetic subjects [M Phil Thesis]. Dhaka: University of Dhaka; 2000.

24. Al-Mahmood AK, Hassan Z, Zinnat R, et al. Insulin secretion and insulin sensitivity in Bangladeshi type 2 diabetic subjects. International Med J 2007; 14: 295-298.

25. Mojlish UKFK. Role of resistin in pathophysiology of Type 2 Diabetes Mellitus in Bangladeshi population [MPhil Thesis]. Dhaka: University of Dhaka; 2008.

26. Islam N, Hossain M, Hafizur RM, et al. Fasting glucose to adiponectin ratio is associated with the development of type 2 diabetes mellitus. Journal of Diabetology 2011; 3: 3 .

27. Yamauchi T, Kamon J, Waki H, et al. The fat-derived hormone adiponectin reverses insulin resistance associated with both lipoatrophy and obesity. Nature Medicine 2001; 7: 941-946.

28. Nakano $\mathrm{Y}$, Tobe $\mathrm{T}$, Choi-Miura $\mathrm{NH}$, et al. Isolation and characterization of GBP28, a novel gelatin-binding protein purified from human plasma. J Biochem 1996; 120: 803-812.

29. Spranger J, Kroke A, Mohlig M, et al. Adiponectin and protection against type 2 diabetes mellitus. Lancet 2003; 361: 226-228

30. Annuzzi G, Bozzetto L, Patti L, et al. Type 2 diabetes mellitus is characterized by reduced post prandial adiponectin response: a possible link with diabetic postprandial dyslipidemia. Metabolism 2010; 59(4): 567-574.

31. Winer JC, Zern TL, Taksali SE, et al. Adiponectin in childhood and adolescent obesity and its association with inflammatory markers and components of the metabolic syndrome. J Clin Endocrinol Metab 2006; 91(11): 44154423.

32. Chandran M, Phillips SA, Ciaraldi T, et al. Adiponectin: more than just another fat cell hormone? Diabetes Care 2003; 26:2442-2450. 